\title{
Assessment of the Advantages and Limitations of Installing PV Systems on Abandoned Dumps ${ }^{\dagger}$
}

\author{
Marwan Al Heib *(D) and Auxane Cherkaoui
}

\section{check for}

updates

Citation: Al Heib, M.; Cherkaoui, A. Assessment of the Advantages and Limitations of Installing PV Systems on Abandoned Dumps. Mater. Proc. 2021, 5, 68. https://doi.org/10.3390/ materproc2021005068

Academic Editor:

Konstantinos Simeonidis

Published: 9 December 2021

Publisher's Note: MDPI stays neutral with regard to jurisdictional claims in published maps and institutional affiliations.

Copyright: (c) 2021 by the authors. Licensee MDPI, Basel, Switzerland. This article is an open access article distributed under the terms and conditions of the Creative Commons Attribution (CC BY) license (https:// creativecommons.org/licenses/by/ $4.0 /)$.
Institut National de l'environnement Industriel et des Risques (Ineris), Parc Alata, 60550 Verneuil-en-Halatte, France; auxane.cherkaoui@ineris.fr

* Correspondence: marwan.alheib@ineris.fr; Tel.: +33-3-54406614

+ Presented at International Conference on Raw Materials and Circular Economy, Athens, Greece, 5-9 September 2021.

\begin{abstract}
The feedback from international practice has shown that the installation of photovoltaic (PV) parks on abandoned dumps is one of the best environmental and economical solutions. This paper discusses the site selection criteria for the installation of PV systems on dumps. When installing the PV systems, different environmental, technical, and economic criteria should be respected. The ground movement and combustion hazards in the dumps appear to be the main constraints and limitations for the installation of photovoltaic panels. This paper presents several examples of the installation of photovoltaic panels on coal-lignite dumps in France. However, the number of projects is still very limited compared to the identified potential.
\end{abstract}

Keywords: dumps; photovoltaic panels; criteria; post-mining hazards

\section{Introduction}

One of the biggest challenges in the coal mining industry is waste disposal during and after the mining operation [1]. The ratio of the volume of the waste material to coal or lignite ranges between $<1: 1$ and $>10: 1 \mathrm{~m}^{3} / \mathrm{t}$ throughout Europe [2]. Mining and quarrying activities in Europe generate approximately $55 \%$ of total industrial wastes, according to a recent Eurostat report (https: / / ec.europa.eu/eurostat/fr/, accessed on 1 June 2020). In China, coal mining waste, including overburden and waste rock, accounts for $40 \%$ of all solid wastes [3]. Pamer et al. [4] stated that approximately $50 \mathrm{mtpa}$ of colliery discard was being stored above ground in dump heaps. Chmielewka and Otto [5] mentioned that the Ruhr district of Germany has 104 dump tips, where the large majority are from coal mining activity. One thousand three hundred coal tailings have been identified in France [6]. It is estimated that there are 200 coal waste dumps in Poland, with a total area of 4000 ha [7].

The identification of sustainable reuse opportunities for dumps is undoubtedly a modern and attractive business. The circular economy (CE) of the coalmine regions is a sustainable development strategy proposed to tackle environmental degradation problems. The waste from coal mines may be used for different types of engineering works, including re-cultivation and leveling of degraded areas, highway engineering, cement production, and mining (e.g., hydraulic stowing). These new economic activities represent a potential for job creation, increased revenues, revitalization, economic development, and stability for local and regional energy grids [8].

\section{Hazards of Existing Dumps}

The reuse and the valorization of abandoned dumps are very attractive economic activities. However, dumps are industrial installations and can potentially present longterm hazards. The main hazards related to dumps are ground movements and dump fires (Figure 1). Slope instability remains the main long-term hazard. The long-term stability of the dump is a key objective for the safety and security of mining regions. However, local 
and global landslides have been observed during and after abandoned mining activities. Between 2000 and 2008, 43 coal impoundment failures and incidents were reported in the USA [9]. The second major hazard is the fire and combustion of the dump material. Residues from coal and lignite mines are likely to be affected by in situ combustions and/or reactivation by external fire. The heaps most likely to burn are heaps of mine or pit constituted of products from digging rock galleries, coal tracks, and residues of the extracted coal.

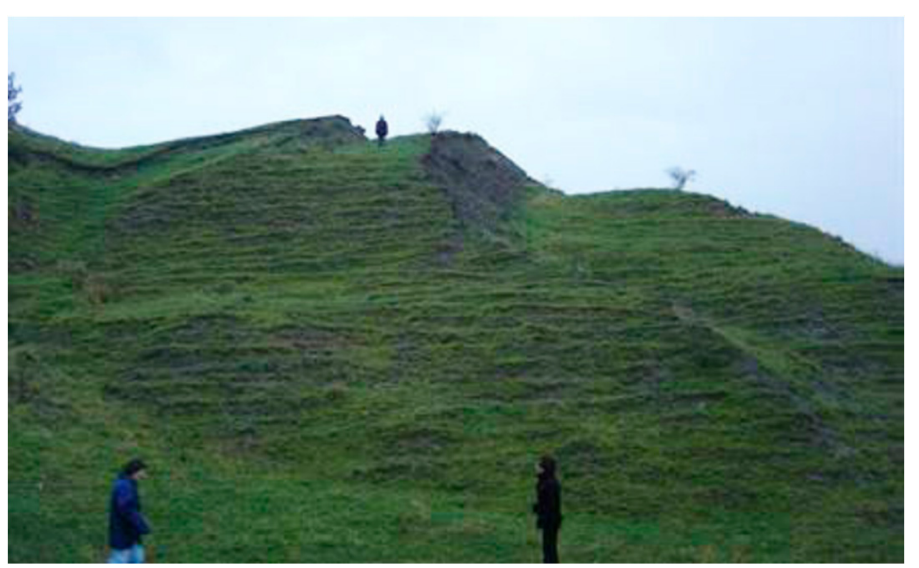

(a)

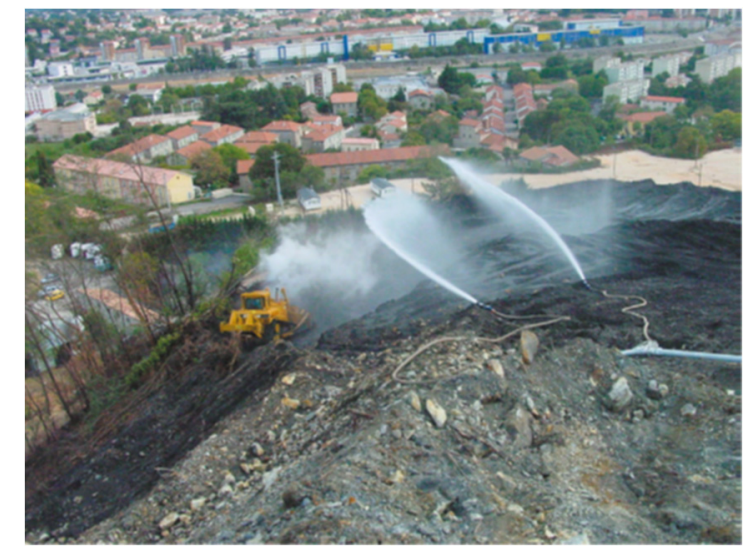

(b)

Figure 1. (a) Deep landslide in a dump (Ineris credit), and (b) dump combustion, with watering and treatment to reduce the combustion risk (credit Ineris).

Dumps can potentially present environmental hazards and risks, such as dust on exposed facilities and soil contamination due to the seepage of water through the waste rocks and soil of the dump. Typical problems in lignite dumps are high salt wash-off and acid rock drainage. Tailing materials pose similar environmental problems to dumps, as milling and flotation renders the formerly secluded minerals more reactive. Due to the even smaller grain size of tailings, these problems are further amplified.

Overall, the intensity and the nature of hazards depends on the dump location, the construction method of the dump, dump geometry, dump material, heavy rain, etc. The aim of valorization is to reduce, as far as possible, the negative effects of mining and to regulate the waste produced by the mining industry. Nevertheless, not all the dumps can be revitalized, and they generally can be divided into three categories: revitalization at the current state; revitalization with additional investigation and improvement of safety and stability; and inability of revitalization, which presents a high risk because of the existence of residual risk. A risk assessment study should be carried out to assess the feasibility of the revitalization project.

\section{Renewable Energy Installation: Site Selection Criteria}

Solar power is an unlimited source of energy available all over the world. Many factors influence the decision to install photovoltaic panels in general, such as legal, environmental, technical, financial, and socio-economic factors $[10,11]$. The environmental factors that should be considered include visual impacts, land use intensity, wildlife impacts, reflection effects, depletion of natural resources, and waste management. The financial factors are closely related to the technical factors, and include the location of the PV park relative to power lines, available sunlight hours, and more. The installation cost depends on the land use, solar resources, network connection constraints, and restrictions due to ground slope. Access to a road is also an important factor to be considered in any large-scale PV project $[4,12,13]$. The following sites can be considered very suitable for the installation of photovoltaic farms: 
- $\quad$ Degraded lands (industrial wastelands, old open pit mines and dumps, etc.);

- $\quad$ Sites with low potential in terms of agronomic soil value and fauna and flora;

- Sites with development of activities (grouping with other renewable energies, such as wind);

- Sites that are not exposed to natural and/or technology hazards, and have a low impact on the landscape.

Abandoned coal mines and dumps are considered suitable sites for PV installation. Coal mine sites, including dumps and heaps, can provide economic value and contribute to energy production in the EU states. Using abandoned open-cast coal mines and their surroundings are useful for the installation of utility-scale solar PV systems. Furthermore, abandoned mining sites may be in areas that are not well-suited for more traditional commercial or industrial reuse opportunities. However, the potential for renewable installation depends on dump site's location, mine hazards, and other power sourcing options near the dumps and mine sites.

\subsection{PV Installation}

The social and economic criteria are generally acceptable for the reuse of dumps as PV farms. These sites can take advantage of local renewable resource attributes to generate electricity or produce power in a manner that increases energy efficiency, reduces the environmental impact of generation, and enhances energy diversity while returning these lands to productive reuse. The PV panel installations require relatively large areas for deployment, where dumps can offer the necessary land.

Many dumps are located near existing mining infrastructure, including roads and power transmission lines, due to prior mining activities. The availability of existing infrastructure can reduce project costs. In addition, many dumps are situated in remote areas with limited electricity infrastructure, making them well suited for the use of solar energy for on-site clean-up and reclamation activities.

\subsection{Limitation of the PV Installation}

Dumps can present technical limitations for PV installation, primarily regarding mine hazards:

- Steep slopes: the angle of slope is a very important parameter, and may be a limitation of the reuse of dumps for photovoltaic installation. This situation presents challenges for the stability of the foundation and for the anchoring system, due to the increasing the wind loads on the panels, worsening the impact of stormwater, increasing the effects of the erosion, and decreasing the stability of the dump.

- Combustion and fire risk: a PV system can release large amounts of heat in spots in the case of a malfunction, and thereby can become a fire source. PV modules are combustible, irrespective of their technology and design. The PV module can independently continue burning in the event of a full-scale fire. However, the fires caused by PV systems are fortunately rare. Thus, the installation of the PV system on coal or lignite can increase the fire hazard of the dump. A risk assessment should be carried out to mitigate such hazards [14]. In the case of intervention on "cold" heaps containing combustible materials, the risk of overheating must be considered.

- Settlements: the installation of a PV system on fresh soil and unconsolidated material can produce a deferential settlement. Uncompacted soil in the dump and combustion can produce important deferential settlements, causing instability in the installation.

- Gas production: gas production due to the existing residual quantities of coal and lignite may affect the installation of the PV system. Gas production can be the result of accidental fire initiated by electric cable heating.

- Dust production: the soil in dumps can contain a non-negligible amount of small particles. Dust deposition on the panels during windy days can affect the efficiency of the PV system. These particles absorb 15\% of the shortwave energy from the sun. For very small particles, during a dry period, the dust can cover the panel and reduce 
the productivity of the installation. As a result, the dust can decrease the efficiency of energy production and increase the maintenance cost.

- Flooding risk: a review of flood risk should be undertaken to determine if there are any areas of high flood risk associated with the site. Existing and new drainage should also be considered to ensure run-off is controlled to minimize erosion.

Additionally, economic and technical aspects, such as transmission access, high upfont cost, cost of storage, permission, preparation of the site, and the installation of the PV system on the dump can present serious limitations for installing PV systems on dumps. Regarding local social and environmental constraints, the reuse and valorization of dumps for renewable energy, and the installation of PV panels on the dumps, may be considered as a useless project by the population, mainly during the closing of coalmines. Additionally, specific fauna and flora may be installed and developed in dump areas over time, presenting a new challenge for the revitalization of the dumps and the installation of PV farms [15].

\subsection{PV Installation in France}

The French strategy is to increase the share of renewable energy in national production. Furthermore, the national strategy in France guides the development of photovoltaic energy on degraded sites, including abandoned mines or landfill sites. France has had a long history with coalmines throughout all of its territory. Figure 2 presents the main coal and lignite basins.

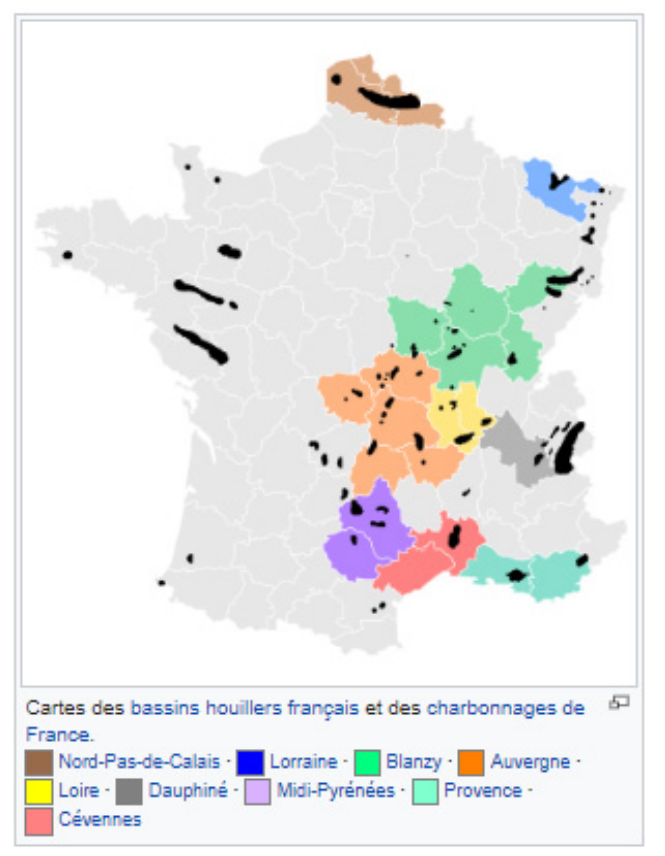

Figure 2. Localization of the main coal and lignite basins in France (source Charbonnages de France).

More than 339 dumps are localized in the Nord-Pas-de Calais Mining Basin. In this basin, the mining waste lands occupy a surface of 3500 ha [16]. Different revitalization projects have been developed covering geotourism, museums, agriculture, and sport activities. Even with a large number of dumps, there has been a few renewable energy installation in the abandoned coal mines. On the Loos-en-Gohelle site, as a demonstration project, 136 experimental photovoltaic panels were installed at the foot of the pit.

In the Provence coal basin, 37 dumps were identified, their surface varies between $1000 \mathrm{~m}^{2}$ and 32 ha. The installation of PV systems was carried out on two of the existing dumps: Sauvaire and Bramefan. The surface of the Bramefan dump is 75 ha. The installation of the PV systems concerned mainly the horizontal part of the dumps. The surface of Sauvaires (Figure 3) is $35 \mathrm{ha}$, and it occupies a valley. The water flows were channeled 
under the deposit. Before the installation of the PV panels, the pipeline was partially closed, and pumps were placed to evacuate water accumulating upstream, where 38,200 modules with a power of $9.36 \mathrm{MWp}$ were installed. The solar power plant produces the equivalent of the electricity consumption of $50 \%$ of the city of Gardanne each year. The photovoltaic plant does not generate any additional hazards or pollution.

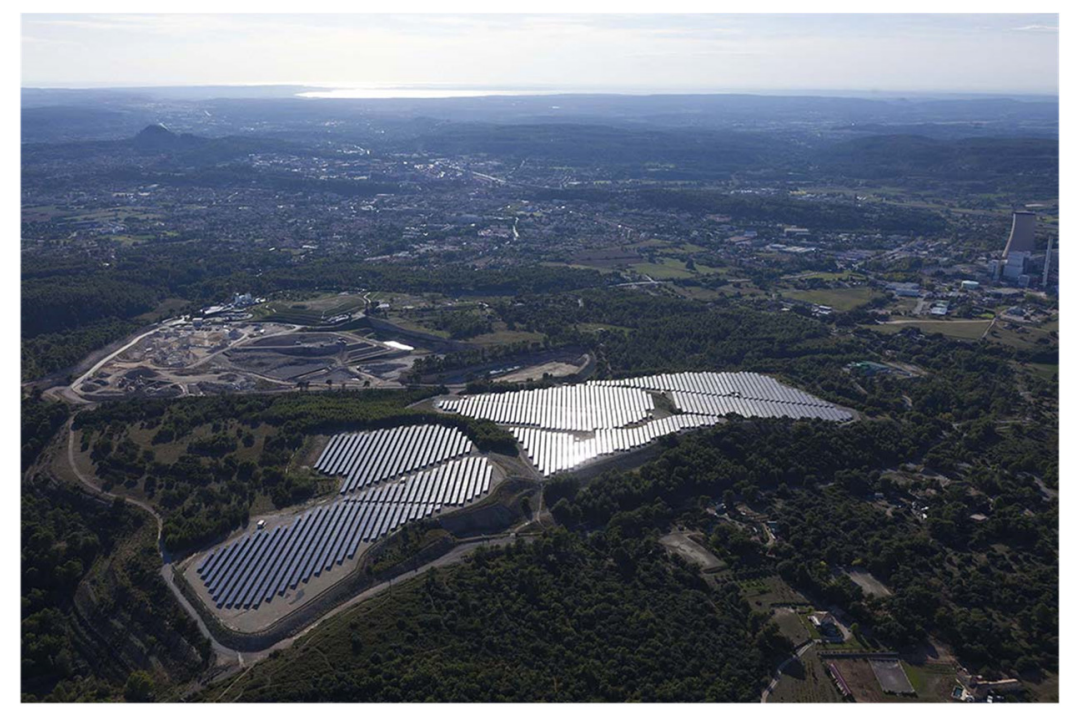

Figure 3. Installation of PV system on the Sauvaire dump in the Provence coal basin (France, crit Urbasolar).

Several dumps exist in the Lorraine coal basin. A photovoltaic park of 12 megawatts was installed on the most important dump site, called Wendel. The Wendel heap covers an area of 117 ha, with deposits consisting of waste rock. The dump is in the form of a vast plateau. The main hazard of the project is the combustion of residual coal. The Wendell dump kept fenced and is being monitored by the Mining Police. Beyond this zone, there are two hot spots for combustion in the south-west and south-east of the slag, which are also monitored. The main challenges of the project are the production of renewable energy, and the preservation of biodiversity and natural habitats.

Another example concerns the installation of four PV parks on the abandoned open mine of Carmaux (France). In June 201836000 PV panels were installed on more than 14 ha. The study took more than nine years. The amount of energy produced is about $13 \mathrm{GW} /$ year. This energy can fulfil the needs of 10,000 inhabitants. Based on these French examples, the installation of PV systems on dumps will progressively increase to meet the national energy demand.

\section{Conclusions}

The installation of PV systems on abandoned coal mines (degraded land) and specifically on dumps is sensible and is supported by the European Commission and national authorities. The strategic approaches for reusing and revitalizing dumps are that, once geotechnically stable and environmentally remediated, they could be repurposed for investments into new low-carbon industries, such as the installation of PV systems on dump lands.

This paper demonstrates that the revitalization of dump zones is profitable for communities, and corresponds to the main objective for coal regions in transition.

The mining hazards should be assessed to predict and mitigate any potential hazard and risk related to previous mining activities. The specific characterizations of dumps presents a challenge for investments. The current situation has shown few PV installation projects and installations in Europe. Technical progress and adopted solutions can overcome the limitations related to dump specifications. 
Author Contributions: Methodology, M.A.H. and A.C.; investigation, M.A.H. and A.C.; writingM.A.H. All authors have read and agreed to the published version of the manuscript.

Funding: This work received funding from the European Union's Research Fund for Coal and Steel under the project "Sustainable Use of Mining Waste Dumps (SUMAD)". No 847227. Financial assistance by the European Commission is much appreciated.

Institutional Review Board Statement: Not applicable.

Informed Consent Statement: Not applicable.

Data Availability Statement: All the data are include in the paper.

Acknowledgments: Ineris thanks the European Union's Research Fund for Coal and Steel for supporting the project.

Conflicts of Interest: The authors declare no conflict of interest.

\section{References}

1. Golam. Base Material Characterisation of Dump at BLA Coal Mines. Master' Thesis, School of Civil Engineering, Queensland University of Technology, Brisbane, Australia, 2015. Available online: https:/ / eprints.qut.edu.au/90717/ (accessed on 12 May 2021).

2. Ernst \& Young. The Growing Role of Renewable Energy; Ernst \& Young, Global Cleantech Canter: London, UK, 2014. Available online: https://www.ey.com/Publication/vwLUAssets/EY_-_Mining:_the_growing_role_of_renewable_energy/\$FILE/EYminingthe-growing-role-of-renewable-energy.pdf (accessed on 8 May 2019).

3. Wozniak, J.; Pactwa, K. Overview of Polish Mining Wastes with Circular Economy Model and Its Comparison with Other Wastes. Sustainability 2018, 10, 3994. [CrossRef]

4. Palmer, D.; Gottschalgabc, R.; Bettsa, T. The future scope of large-scale solar in the UK: Site suitability and target analysis. Renew. Energy 2019, 133, 1136-1146. [CrossRef]

5. Chmielewska, M.; Otto, M. Revitalisation of dump tips and socio-economic polarisation-A case study of Ruhr area (Germany). Environ. Socio Econ. Stud. 2014, 2, 45-56. [CrossRef]

6. Guezennec, A.-G.; Bodénan, F.; Bertrand, G.; Fuetes, A.; Bellefant, G.; Lemière, B.; d'Hugues, P.; Cassard, D.; Save, M. ReProcessing of Mining Waste: An Alternative Way to Secure Metal Supplies of European Union, REWAS 2013: Enabling Materials Resource Sustainability; TMS (The Minerals, Metals \& Materials Society): Pittsburgh, PA, USA, 2013; pp. 231-237.

7. Bednarczyk, Z. Slope instabilities in polish open-pit mines. In Landslides and Engineered Slopes Experience, Theory and Practice: Proceedings of the 12th International Symposium on Landslides, Napoli, Italy; Stefano, A.L.C., Luciano, P., Claudio, S., Eds.; CRC Press: Raton, NM, USA, 2016.

8. Dias Alves, P.; Kanellopoulos, K.; Medarac, H.; Kapetaki, Z.; Miranda-Barbosa, E.; Shortall, R.; Czako, V.; Telsnig, T.; VazquezHernandez, C.; Lacal Arántegui, R.; et al. EU Coal Regions: Opportunities and Challenges Ahead; EC. JRC Science for Policy Report; Publications Office of the European Union: Luxembourg, 2018.

9. CIP 2004. Coal Impoundment Project. Annual Report 2003-2004. Wheeling Jesuit University, West Virginia. Available online: http:/ / www.coalimpoundment.org/reports (accessed on 12 May 2021).

10. Georgiou, A.; Skarlatos, D. Optimal site selection for sitting a solar park using multi-criteria decision analysis and geographical information systems. Geosci. Instrum. Method Data Syst. 2016, 5, 321-332. [CrossRef]

11. Mierzwiak, M.; Calka, B. Multi-Criteria Analysis for Solar Farm Location Suitability. Reports on Geodesy and Geoinformatics. Rep. Geod. Geoinformatics 2017, 104, 20-32. [CrossRef]

12. Noorollahi, E.; Fadai, D.; Akbarpour Shirazi, M.; Ghodsipour, S.H. Land Suitability Analysis for Solar Farms Exploitation Using GIS and Fuzzy Analytic Hierarchy Process (FAHP)—A Case Study of Iran. Energies 2016, 9, 643. [CrossRef]

13. Kereush, D.; Perovych, I. Determination criteria for optimal site selection for solar power plants. Geomat. Landmanag. Landsc. 2017, 39-54. [CrossRef]

14. Sepanski, A.; Reil, F.; Vaaßen, W.; Janknecht, E.; Hupach, U.; Bogdanski, N.; van Heeckeren, B.; Schmidt, H.; Bopp, G.; Laukamp, H.; et al. Assessing Fire Risks in Photovoltaic Systems and Developing Safety Concepts for Risk Minimization. 2015, TÜV Rheinland Energie und Umwelt GmbH. Available online: https:/ / www.energy.gov/ eere/solar/downloads/assessing-fire-risksphotovoltaic-systems-and-developing-safety-concepts-risk (accessed on 12 May 2021).

15. Hélène, F.; Marie-Dominique, S.; Maxime, M.; Maxime, V.; Laurent, V.; Pascale, P.; Jacques, R.; Isabelle, L.-S. Approches spatiales et temporelles des capacités de restauration du terril du Defens (Meyrieul) par Spartium junceum. OHM Bassin minier de Provence. 2017. Available online: https:/ / www.ohm-provence.org/IMG/pdf/8-folzer.pdf (accessed on 12 May 2021).

16. O'MIEL, C. The procedure for registering the Nord-Pas-de-Calais mining basin on the Unesco World Heritage List. In Les Paysages de la Mine, a Contested Heritage? Historic Mining Center Edict (In French); Mission Bassin Minier: Lewarde, France, 2008; pp. 192-201. 